\title{
WhatsApp Groups and Generation X: A New Mode of Social Interaction
}

\author{
Bagus Kendhit Jolonidhi ${ }^{1,}$ Hartiati Sulistyo Rini ${ }^{2 *}$
}

\author{
${ }^{1}$ Department of Sociology and Anthropology, Universitas Negeri Semarang \\ ${ }^{2}$ Department of Sociology and Anthropology, Universitas Negeri Semarang \\ *Corresponding author. Email: hartatisulistyorini@mail.unnes.ac.id
}

\begin{abstract}
The purpose of this study was to determine the reasons for Generation X to use social media and especially WhatsApp Groups (WAG), the interactions they were having and the impact their use of social media was having. A descriptive qualitative case study methodology on a Generation-X WAG in Boyolali, Central Java was employed in this study using interviews, observation, and documentation reviews. It was found that 1) WAGs were the most rational choice for Generation X to connect with friends from the past; 2) the group members had both associative and dissociative social interactions and sent each other a wide range of information; and 3) the impact of the use of WAG expanded the members' social interactions, increased their use of social media, and helped them mediate the real world; however, there were concerns about their degree of digital/media literacy.
\end{abstract}

Keywords: Social Interaction, Social Media, WhatsApp Group, Generation

\section{INTRODUCTION}

Developments in communications technology over the last 20 years have significantly changed the way people interact and communicate. Since it was developed in the early 1960s and commercialized in the 1990s (Guerdon, 1997), the internet has become an essential part of people's daily lives. The Indonesian Internet Service Providers Association (APJII) in 2017 reported that 143.26 million or $54.68 \%$ of the 262 million people in Indonesia were regular internet users: $49.52 \%$ of 19 34 year olds, $29.55 \%$ of $35-54$ year olds, $16.68 \%$ of $13-$ 18 year olds, and the $4.24 \%$ of people> 54 years old (APJII, 2019).

It has been found that $87.13 \%$ of people use the internet for social media activities(APJII, 2019), which here is defined as computer-mediated communication (McIntyre, 2014) (Yohana \& Wulandari, 2014). In fact, Indonesia is ranked third in the world for daily social media use at an average of 3 hours 23 minutes and is also ranked third in the world for its $23 \%$ growth in social media users per year (Kemp, 2018). Many Indonesians also use social platforms such as social networks and messenger/chat apps, with Facebook being the most popular. It was reported in 2018 that there were over 128 million Facebook users in Indonesia, 42 million of which were aged 25-34, and Indonesia is also one of the top- five markets globally for WhatsApp with over 100 million users. (Kemp, 2018).

The emergence of smartphones and instant messaging social media applications such as WhatsApp has created a new medium for group chats over the internet. WhatsApp allows users to send messages and also form conversation groups between two or more people at once. Research has found that people consider WhatsApp as an effective, efficient communication application that has many features (Jisha \& Jebakumar, 2014; Minhas, Ahmed, \& Ullah, 2016; Ngonidzashe, 2016), which along with smartphones, is widely used in Indonesia in everyday life. Smartphones are used by $60 \%$ of all adults in Indonesia who use electronic communication devices (Kemp, 2018), and the WhatsApp application is the main application that people install on their mobile phones (Kemp, 2018), replacing mailing lists, Facebook groups, and sending of information via SMS or telephone (Roikan, 2016).

In general, social media use is highest in people aged 15-30, with most users being students, civil servants, and workers in private companies (Abraham, 2014). However, social media is being widely used by middleaged and older people. In the US, social media is being used by all age groups, with the number increasing every year. Data from February 2019 found that $80-90 \%$ of 
people aged $18-49,69 \%$ of people aged $50-64$ and $40 \%$ of people aged more than 65 years were regular social media users (P. R. Center, 2019), which indicated that social media and its associated features was becoming common place in all age groups (Rosales \& FernándezArdèvol, 2016).

Generation X (who were born from the late 60s to the late 1980s) Indonesians commonly use social media. Mannheim defined generations as a social construct for groups of people around the same age who had the same social and historical experiences (Putra, 2017). Different dates have been suggested for Generation X (1961-1981 or 1965-1985), and it has been found that this group tends to express a nostalgia for the past (Wilson, 1999). Generation $\mathrm{X}$ was born in the early years of the technological and information revolution and were children, teens, and young adults when personal computers (PCs), video games, cable TV, and the internet emerged (Putra, 2017). This study targeted Generation X consider that while there have been many studies on the social media habits of younger people (Abraham, 2014), there has been less focus on the social media use of the generation born at the beginning of the information revolution (between 1961-1981).

As the internet has now penetrated the rural-urban and even rural areas, people can use social media to communicate with families, friends, alumni and coworkers and reunite and reconnect with family and friends with whom they have lost touch; in other words, social media can be widely used to stay in touch with family and friends (Errika, 2011). As long as the internet and cell phone networks are available, people can access the internet and use social media. WAGs have become a popular social media applications as WhatsApp is integrated into smartphones and provides interactive multimedia services that allow for the sharing of text, pictures or videos (Van Dijk, 2012).

This study examined the use of the WhatsApp application and especially the WhatsApp group (WAG) function by Generation X SMP (Junior High School) alumni from Karanggede, Boyolali, Central Java. The main research questions for this study were as follows: Why does Generation X use WAG applications?; What are the main group member social interactions and what types of information are being exchanged?; and What are the impacts from using WAG social media functions?. The findings from this study add to social media research (Castells and Cardoso, 2006), and media literacy resources and appropriation theories (Van Dijk, 2017).

\section{RESEARCH METHOD}

A descriptive qualitative research method approach with a case study analysis on one Generation-X WAGs in Boyolali, Central Java was employed for this study. Even though Boyolali, Central Java is in a rural area, the people are connected with the world as they have access to computers and smartphones (Sacramento City College 2019). For this study, members of a WAG in Boyolali, who use the application to stay in contact with alumni from their junior high school, were interviewed, observations conducted, documentation based on the members activities were reviewed, and an interactive qualitative analysis model used for the data analysis, which involved collecting data, reducing the data, presenting the data, and drawing conclusions.

\section{DISCUSSION}

The WAG of the alumni SMP 1 Karang gede was formed on January 16, 2016 and, as of April 2018, had 71 members, most of whom had graduated junior high school in 1980 and $60 \%$ of whom were male. The members had widely varying professions, with $25 \%$ being teachers and the others working as entrepreneurs, employees, housewives, civil servants, soldiers, medical personnel, laborers, and lecturers. Initially, most WAG members lived in Karanggede and the surrounding areas; however, now alumni live in many other cities on Java and outside Java. Even though Karanggede is a semirural district in the northern part of Boyolali Regency, Central Java Province, it is easy for the members to keep in touch because the region has internet access: there are five towers in Karanggede that are owned and operated by cell phone companies, two towers owned and operated by Telkomsel and the rest being owned by XL Axiata, Indosat, and 3, all of which provide $4 \mathrm{G}$ internet networks; therefore, even in this region, internet services are affordable and easily accessible by all.

\subsection{WAG as a Rational Choice for Interaction and Communication}

The WAG was chosen for social interaction because it is connected to a telephone number, can be used at any time, privately or in groups, and provides a variety of multimedia services (e.g., text, photos, and videos) in one application. Previously, the group had tried using Facebook but had encountered difficulties, such as having to go through many stages before being able to access features such as groups or private conversations, and being unable to instantly access notifications on Facebook because of the need to log-in first. Therefore, because of the low cost, there has been an almost universal adaptation of many of these WAG tools to maintain contact with friends and family (Antonucci, Ajrouch, \& Manalel, 2017).

\subsection{Variety of Social Interactions and Information Choices}

The alumni social media group had several kinds of social interactions processes. Gillin and Gillin stated that there were two kinds of social processes associated with social interactions; associative (social processes that are 
closer or unifying) and dissociative (social processes that distance or contrast) (Sumarti, 2015).

Associative social processes open up wider access to information and strengthen social ties between group members. The first associative process found in the WAG was the sharing of information and knowledge updates, and the second associative social process was associated with the strengthening of social ties. Because this social media group were alumni, many joined the group to reconnect and restart communication with people that they may have lost contact with. Therefore, while many of the conversations are related to the past, they also discuss the present day activities, with some planning to meet in person. Social interactions through the internet have been found to make people feel close and intimate with other online users (Abraham, 2014), which can strengthen the social ties between the group members; for example, when there are group members in trouble, the other members pull together to provide support.

The information that is shared in this group is diverse, from light and entertaining to information that gives new knowledge. From the beginning of the WAG, there was a consensus that the information to be shared should not be related to politics, should be free from racial issues (e.g., ethnicity, religion, race, class), and should not be for the mutual interest of a member

The group members stated that political issues were avoided because they could lead to misunderstandings and even conflicts among the members. Research in other groups in 2018 found that political issues were warmly discussed and the experiences used as valuable examples. However, in some other groups, arguments about politics resulted in people leaving the group because of discomfort and political differences.

Racial issues were avoided to protect feelings, with the group members committed to conversations that strengthened the bonds between the members and broke down barriers. It was evident that the professional backgrounds of the people in the group provided a varied source of information. Issues involving personal interests were also avoided. Group members felt that it was inappropriate to discuss their sex interests, in principle, and if someone wanted to share their personal or family problems, they were encouraged not to join this social media group.

The WAG information that was shared was as follows; greeting each other, humor or jokes, good and inspirational information, buying and selling offers, personal information about members, general information related to conditions in the area, reunion invitations, and health information.

Greetings were a WAG social interaction activity that was carried out every day. At around 7:00 a.m. to 8:00 a.m., the WAG becomes crowded with mutual greetings and enthusiastic support for the activities of the day. Humor and jokes were lightweight and were delivered at any time and ranged from general to adult humor. Usually group members responded with words or laugh symbols for the general humor but adult humor was not always accepted by all members.

The inspirational messages were from group members who sent religious-themed pictures or texts that reminded or invited other members to always have good habits and to worship. On July 3, 2018, for example, one member sent a picture of a hadith of kindness for the evening prayer, to which many members responded. The message was sent at 2:40 a.m. and over the next 1.5 hours, other members sent invitations to perform the Fajr prayer, to which many members also responded.

Bids for buying and selling goods are also done through group interactions. Items that have been offered in this group are land, houses, and vehicles (e.g., motor bikes and cars). If any group members are interested, the chat is continued through private channels so as not to interfere with the social interactions in the group. The solidarity between the alumni makes it easier and quicker to buy and sell as there is a higher level of trust when buying or selling from fellow alumni.

Reunion invitations are often discussed as these are the main binders for the group interactions. Planning for the reunion activities is carried out by seeking group member opinions related to the time, place, and content of the reunion event.

The personal information shared in the WAG includes marriage information about the children of the group members and information about colleagues who are sick or have passed away. One member stated that he had delivered his son's wedding invitation using the WAG as the invitation was intended for all group members and made it easier for group members to accept. This also has many advantages for the invitee as there is no need to pay for, print, or send invitations, the invitations can be quickly distributed, and they can quickly know who can and cannot attend the event. Other personal information given in the group is about members/people they know in common who have passed away. For example, information was shared about the death of one of the former junior high school teachers, which elicited rapid responses as the news quickly spread expressing condolences and discussing arrangements to visit the funeral together and pay their respects.

General information about the latest news is also shared in the group. For example, one member let everyone know about the increase in the price of nonsubsidized fuel on July 1, 2018 and the schedule of a police raid throughout Indonesia. When the news was shared, the informant also mentioned the news source.

As the group members' ages range from 50 to 60 , health information is often shared. While there are not 
very many responses to this information, members keep it to read when they have time. Some traditional care and treatments are also shared.

Dissociation results in conflicts between members due to differences in opinion, the limitations of written communication,

and miscommunication/misunderstanding. Differences of opinion in social interactions are inevitable, and can provoke two main actions; reacting and staying quiet without giving a response. Positive reactions are often marked by the use of emoticons and supportive comments, but negative reactions are generally protests or expressions of hope that the content will not be propagated. Negative responses are given to content that is deemed inappropriate. This often happened when humorous content was given a sensual interpretation that touched on pornography. The use of written language is also a challenge in social interactions as the choice of words, the size of the letters, the use of punctuation, and if not chosen carefully, the choice of emoticons can be misinterpreted and trigger miscommunication. Sometimes, small things can result in big and even excessive reactions if not delivered properly.

The information shared between the group members was generally in line with their age. In the WAG, most responses from members are solicitations for social activities, the giving of personal information between members, reunion invitations, and health information. According to the group members, all interactions in the group are associative as the social interactions in the group are meant to provide entertainment and refreshing content to help them through the day. This was related to the limited activity of some members due to age or retirement.

\section{IMPACT OF THIS NEW MODE OF SOCIAL INTERACTION}

From the discussions with the WAG groups, the following observations were made. First, this new social interaction mode using WAG social media allowed people to expand their range of interactions, both socially and informationally. The group's members felt that they were more social, had more friends and contacts, and were more socially and politically active than non-users; that is, there have been sociability transformations (Castells \& Cardoso, 2006). Information that originally took a long time can now be delivered in real time and is easily accessible by the wider community. In the current information age, networks between two points (or social positions) are shorter (or more frequent, or more intense) if they are nodes in the same network (Castells, 1996).

The second impact was the adoption of the social media interactive mode by Generation $\mathrm{X}$, which means that they adopted new patterns of behavior. There are certain times when the social interactions became intense in the WAG; from $02.00 \mathrm{WIB}$ to $07.00 \mathrm{WIB}$ (invites to
Tahajud pray until Fajr); greetings in the morning via WAG to encourage each other to start the day; in the afternoon from 17.00 WIB to $18.00 \mathrm{WIB}$; in the evening from 19.00 WIB to 24.00 WIB (the last two times are seen as free time so more humorous content and light information is shared). Therefore, most members are fully embracing this new media as they are logging in to their profiles several times a day (Mustafa \& Hamzah, 2011).

The third impact of the use of social media by Generation $\mathrm{X}$ was that the mediated interactions in the WAG allowed for more frequent direct social interactions. Because the members are an alumni social group, they often share memories from the past, which stimulates invitations for face-to-face meetings. Even WAG members who are geographically separated or far from the hometown try to meet directly more than once a year, which is more often than regular alumni meetings.

One member stated that the reunion invitations delivered in the group were followed up by meetings at the real event. He said that he often visited his hometown to see his friends both for Eid celebrations and when he is on longer stays, at which times he takes the opportunity to meet with group members. Therefore, the online communication leads to offline and face-to-face communication, which further strengthens the group member bonds (Van Dijk, 2012).

The fourth impact is related to media literacy, which can be a challenge for some Generation X-ers. Each generation has its own dynamics and challenges. Each generation has similar social characteristics in terms of age, value, and historical life experiences (Mannheim, 1952). The social construct that underlies each generation affects the way they deal with the dynamics of social change. The present values for Generation $\mathrm{X}$, for example, are very different from the values when they were growing up, which is especially true for the use of social media as a means for daily social interaction. The Generation X WAG in this study experienced several challenges: 1) they easily trusted the information conveyed on social media, and 2) they shared news they considered interesting without considering whether it was reliable.

One piece of information that was shared by the group was about a traffic jam at the Salatiga Toll Gate area during Lebaran. One member said that the information obtained from the group was immediately trusted and shared with other groups because the text was detailed, gave a clear description, and was accompanied by images of the congestion in the area.

As outlined in resources and appropriation theory, there are several stages to obtaining accurate information: a) motivation; b) physical and material access; c) digital skills; and d) usage (frequency and diversity (Van Dijk, 2012). However, most of the WAG members do not 
check the news that is circulated through their social media groups; that is, it appears that the members are not fully digitally literate. Gilster stated that digital literacy requires users to critically understand and evaluate the news being circulated through the internet media (Pool, 1997).

For example, on July 4, 2018 at 7:20 a.m., a group member needed information about his retirement savings in Boyolali after the Eid holiday. He asked about this directly to the conversation group, and two minutes later he received a response from one of the other group members; however, as this information was incomplete, another group member responded with clearer information. It was obvious that the information was not immediately accepted by the other members as he showed a critical attitude toward the information by responding "is it right?" However, critical attitudes are rare in group members when commenting on information spread in the WAG as getting at the truth is still not an important part of the social media interaction. A new critical attitude will emerge related to matters that are urgent or in relation to privacy and personal information. In this study, few social interactions were mutually checked, which was possibly related to the characteristics of Generation X. It has been observed that when this generation received information from the internet, they tried to get as much additional information as possible (McHenry and Ash, 2013).

\section{CONCLUSION}

Social media is being widely used for everyday social interactions that cross geographical boundaries and generations. One social media application that has united people is the group function of the WhatsApp application called the WAG. This paper examined a WAG school alumni Generation $\mathrm{X}$ group to assess the value of the communication compared to other social media platforms.

This study found that distinctive community characteristics of rural Indonesia have not prevented the taking up of social interactions using social media applications. These days, all generations are using social media in their daily lives to share information, keep in touch and form specific groups. The benefits of the Generation X WAG investigated in this paper appeared to be greater than the negative effects of using social media. Positively, groups members stated that they were able to have better quality social interactions; however, negatively, it appeared that the group members were not yet fully digitally literate as they tended to trust the news that was shared in the group.

\section{REFERENCES}

[1] Abraham, F. (2014). Pemanfaatan Twitter sebagai media komunikasi massa, Penelit Pers dan Komun. Pembang, 18(1), 171-184.

[2] Antonucci, T. C., Ajrouch, K. J., \& Manalel, J. A. (2017). Social relations and technology: Continuity, context, and change. Innovation in Aging, 1(3), igx029. DOI: $10.1093 /$ geroni/igx029.

[3] APJII (2019). Penetrasi dan Perilaku Pengguna Internet Indonesia.

[4] Castells, M. (1996). The Rise of the Network Society. Oxford: Blackwell Publishing Limited Company.

[5] Castells, M., \& Cardoso, G. (Eds.) (2006). The Network Society: From Knowledge to Policy (pp. 3-23). Washington, DC: Johns Hopkins Center for Transatlantic Relations.

[6] Errika, W. (2011). Komunikasi dan media sosial [Communications and social media]. Messenger, 3(1), 69-75.

[7] Guedon, J. C. (1997). A brief history of internet. Studies in Health Technology and Informatics, 36, 121-132.

[8] Kemp, S. (2018). Digital in 2018: Essential insights into internet, social media, mobile, and ecommerce use around the world [Online]. Retrieved from https://www.digitalinformationworld.com/2018/07/ global-internet-stats-infographic.html

[9] Jisha, K. M., \& Jebakumar, D. (2014). WhatsApp: A trend setter in mobile communication among Chennai youth. IOSR Journal of Humanities and Social Science, 19(9), 01-06. doi: 10.9790/083719970106

[10] Mannheim, K. (1952). The Problem of Generations (pp. 276-322). London: Routledge.

[11] McHenry, W. K., \& Ash, S. R. (2013). Knowledge management and collaboration: Generation $\mathrm{X}$ vs. Generation Y. International Journal of Business and Social Science, 4(12).

[12] McIntyre, K. E. (2014). The evolution of social media from 1969 to 2013: A change in competition and a trend toward complementary, niche sites. Journal of Social Media in Society, 3(2), 5-24.

[13] Minhas, S., Ahmed, M., \& Ullah, Q. F. (2016). Usage of WhatsApp: A study of University of Peshawar, Pakistan. International Journal of Humanities and Social Science, 5(7), 2319-7722.

[14] Mustafa, S. E., \& Hamzah, A. (2011). Online social networking: A new form of social 
interaction. International Journal of Social Science and Humanity, 1(2), 96-104. DOI: 10.7763/IJSSH.2011.V1.17

[15] Ngonidzashe, M. (2016). Social networks and the social interaction in family relationships among Zimbabweans: A survey on the perceptions of residents in Harare and Mashonaland West provinces of Zimbabwe. International Journal of Research, 62, 62-68.

[16] Pool, C. R. (1997). A new digital literacy a conversation with Paul Gilster. Educational Leadership, 55, 6-11.

[17] P. R. Center (2019). Social media fact sheet [Online]. Retrieved from https://www.pewinternet.org/fact-sheet/socialmedia/.

[18] Putra, Y. S. (2017). Theoretical review: Teori perbedaan generasi. Jurnal Ilmiah Among Makarti, 9(18).

[19] Roikan, R. (2016). Forum internet sebagai cyber public space: Analisa Komparasi Kaskus, AdsenseId dan Semprot. Jurnal Pemikiran Sosiologi, 3(1), 69-79. DOI: 10.22146/jps.v3i1.23527.

[20] Rosales, A., \& Fernández-Ardèvol, M. (2016). Beyond WhatsApp: Older people and smartphones. Romanian Journal of Communication and Public Relations, 18(1), 27-47. DOI: 10.21018/rjcpr.2016.1.200.
[21] Sacramento City College (2019). Introduction to sociology.

[22] Sumarti, T. (2015). Interaksi dan struktur social. In F. T. Nasdian (Ed.), Sosiologi umum (pp. 39-64). Jakarta: Yayasan Pustaka Obor Indonesia.

[23] Van Dijk, J. (2012). The Network Society (3 ${ }^{\text {rd }}$ ed.). London, Thousand Oaks, New Delhi: SAGE Publications.

[24] Van Dijk, J. A. (2017). Digital divide: Impact of access. In P. Rossler, C. A. Hoffner, \& L. V. Zoonen (Eds.), The International Encyclopedia of Media Effects (pp. 1-11). Hoboken, NJ: John Wiley \& Sons, Inc. DOI: 10.1002/9781118783764.wbieme0043

[25] Wilson J. L. (1999). Generation X: Who Are They? What Do They Want?. The NEA Higher Education Journal, 9-18.

[26] Van Dijk, J. A. G. M. (2012). The evolution of the digital divide: The digital divide turns to inequality of skills and usage. In: J. Bus, M. Crompton, M. Hildebrandt, \& G. Metakides (Eds.), Digital Enlightenment Yearbook 2012 (pp. 57-75). Amsterdam: IOS Press.

[27] Yohana, N., \& Wulandari, T. (2014). Perilaku komunikasi kelompok komunitas virtual communication groups behaviour of Kaskus virtual community of Riau Raya region, 0761 (pp. 117128). 